\title{
Comparative Antimicrobial Activity of Phytofabricated Ag and Au Nanoparticles from Ledebouria hydrabadensis Rhizome using Various Methods
}

\author{
S. RAJU, D. ASHOK* AND CH. VINUTHNA
}

Green and medicinal Chemistry Laboratory, Department of Chemistry, Osmania University, Hyderabad-500007, Telangana, India

Raju et al.: Antimicrobial Activity of Ledebouria hydrabadensis mediated Ag and Au nanoparticles

\begin{abstract}
The paper reports the comparative study, synthesis and evaluation of antimicrobial activity of silver (Ag) and gold (Au) nanoparticles. These are phytofabricated from root bulb extract of medicinal plant Ledebouria hyderabadensis using various methods such as stirring, sonication and autoclave. Synthesized Ag and Au nanoparticles characterized by multiple instrumental techniques such as the UV-Visible spectroscopy, the maximum absorption peak noted at $436 \mathrm{~nm}$ and $556 \mathrm{~nm}$ indicate the formation of metallic colloidal Ag and Au nanoparticles respectively. The Fourier transform infrared spectroscopy of Ag and Au nanoparticles indicates the phytochemicals proteins, alcohols and phenols present in the Ledebouria hyderabadensis rhizome extract involving in the reduction and stabilization by capping around the Ag and Au nanoparticles. The average particle size found to be below $50 \mathrm{~nm}$ in all the cases except Ag nanoparticles synthesized by the stirring method. The transmission electron microscopy images clearly indicating the nano-sized monoclinic, polyclinic, anisotropic, polydistributed, spherical shaped particles. These Ag and Au nanoparticles exhibited profound antimicrobial activity against harmful tested phytopathogenic fungi Sclerotium rolfsii, Rhizoctonia solani and human pathogenic fungi Aspergillus flavus as well as against human harmful bacteria Escherichia coli, Bacillus subtilis used in this experimentt.
\end{abstract}

Key words: Ledebouria hyderabadensis, Ag and Au nanoparticles, antibacterial activity, human pathogenic fungus, plant pathogenic fungus

The biological synthesis of nanoparticles is attracting stream of research due to ease of availability and renewable plant sources ${ }^{[1]}$. This greener approach using plant materials ${ }^{[2,3]}$, microorganisms ${ }^{[4,5]}$ is a fascinating alternative and shows many benefits over the chemically synthesized nanoparticles because they involve simple reaction processes, non-toxic, environmentally friendly, low cost, energy-efficient and they proved to be stable ${ }^{[6]}$. The previous studies of biologically synthesized silver and gold nanoparticles exert a potential antibacterial effect. Phytochemicals and metabolites ${ }^{[7]}$ having medicinal properties are responsible for the reduction of $\mathrm{Ag}$ and $\mathrm{Au}$ ions into the stable $\mathrm{Ag}$ and $\mathrm{Au}$ particles; meanwhile, they are acting as capping agents by surrounding the particles. The medicinal plant materials consisting of active components produced considerable biological activities. They used in Ayurveda for the cure of many diseases around the globe and India for so many years.

*Address for correspondence

E-mail: ashokdou@gmail.com

September-October 2020
Nanotechnology has emerged as an interdisciplinary subject construct applications in all streams of science and technology. The Ag and Au nanoparticles have biological importance; the combination of these metallic nanoparticles surrounded with active plant components such as alkaloids, polyphenols, carbohydrates, proteins, etc. generated excellent and improvised properties not only in the biological but also in medicine, chemistry and pharmaceuticals ${ }^{[8,9]}$. From the above advantages, many plants previously reported for the synthesis of metallic nanoparticles, alfalfa ${ }^{[10]}$, coriander $^{[11]}$, lemongrass ${ }^{[12]}$, aloevera ${ }^{[13]}$, neem ${ }^{[14]}$ etc. Many studies have existed for the synthesis of Ag and

This is an open access article distributed under the terms of the Creative Commons Attribution-NonCommercial-ShareAlike 3.0 License, which allows others to remix, tweak, and build upon the work non-commercially, as long as the author is credited and the new creations are licensed under the identical terms

Accepted 15 September 2020

Revised 07 September 2020

Received 15 March 2020

Indian J Pharm Sci 2020;82(5):851-860 
$\mathrm{Au}$ nanoparticles using various plant materials ${ }^{[15-16]}$. Synthesis of $\mathrm{Ag}$ and $\mathrm{Au}$ nanoparticles have got an enormous emphasis on the scientific industry because they show controlled geometry ${ }^{[17]}$, stability, different surface morphology, distinctive chemical and physical properties ${ }^{[18,19]}$. Multipurpose applications of Ag nanoparticles previously reported such as the antitumor effect ${ }^{[20]}$, antibiotics ${ }^{[21]}$, antimicrobial effect $^{[22,}$ ${ }^{23]}$, pollution treatment ${ }^{[24,25]}$, molecular switches, electronics $^{[26]}$, materials science, forensic science ${ }^{[27]}$, textile industry, food technology ${ }^{[28]}$, agriculture ${ }^{[29]}$, catalytic $^{[30]}$, drug delivery ${ }^{[31]}$, anti-cancer, sensing, diseases diagnosis ${ }^{[32]}$, therapeutic applications ${ }^{[33]}$ and many more. Ag nanoparticles proved to have efficiency in the anti-microbial effect ${ }^{[34-37]}$.

The production of potent advanced drugs got importance in the $21^{\text {st }}$ century because ever-increasing consequences as microorganism bacteria and fungi are becoming drug resistance. So there is an urgent need to produce efficient multidrug for in opposition to human pathogenic bacteria and fungi. Phytopathogenic fungi result in produce many diseases in the industrial as well as food-based crops around the world. These diseases cause a considerable amount of economic and food product loss because plants are the primary nutrient sources for pathogens ${ }^{[38]}$. Ag nanoparticle's effect on plant pathogens reported previously ${ }^{[39,40]}$. So the synthesis of nanoparticles produces excellent antimicrobial activity against bacteria, fungus in the agriculture field ${ }^{[41-42]}$.

The present work focused on the fabrication of hyderabadensis aqueous rhizome extract using three various methods; those are stirring, sonication and autoclave. To characterize the phytofabricated Ag and $\mathrm{Au}$ nanoparticles using multiple spectroscopic and $\mathrm{Ag}$ and $\mathrm{Au}$ nanoparticles from the Ledebouria

microscopic studies. To perform antimicrobial activity against harmful phytopathogenic, human pathogenic fungi and bacteria. To our knowledge, this is the first report to study the synthesis of $\mathrm{Ag}$ and Au nanoparticles and its applications from Ledebouria hyderabadensis rhizome extract.

\section{MATERIALS AND METHODS}

\section{Chemicals:}

Ledebouria hydrabadensis plant rhizome had been collected locally from Osmania University campus, Hyderabad, India. Silver Nitrate $\left(\mathrm{AgNO}_{3}\right)$ and Chloroauric acid $\left(\mathrm{HAuCl}_{4}\right)$ were purchased from SDFine chemicals Mumbai, India. The bacterial and fungal test strains procured from IMTECH, Chandigarh. The media for the growth of bacterial and fungal strains purchased from Himedia laboratories, Mumbai, India. Glassware used in the investigation was acid washed then rinsed with distilled water thoroughly. Deionized water used throughout the experiment.

\section{Preparation of rhizome extract:}

The Ledebouria hydrabadensis collected rhizome (41.19 gm) shown in (fig. 1a) upper layer was removed and cleaned using running tap water followed by rinsing with the distilled water to get rid of earth crust then ground to a fine paste with mortar and pestle. The paste was directly mixed with $1000 \mathrm{ml}$ of distilled water and kept for stirring using magnetic stirrer at $500 \mathrm{rpm}$ and heating temp at $60^{\circ}$ for $1 \mathrm{~h}$. After stirring the clear white color plant extract solution shown in (fig. 1b) is filtered and collected in a $1000 \mathrm{ml}$ screw cap bottle and stored at $4^{\circ}$ for further use in the fabrication of $\mathrm{Ag}$ and Au nanoparticles.

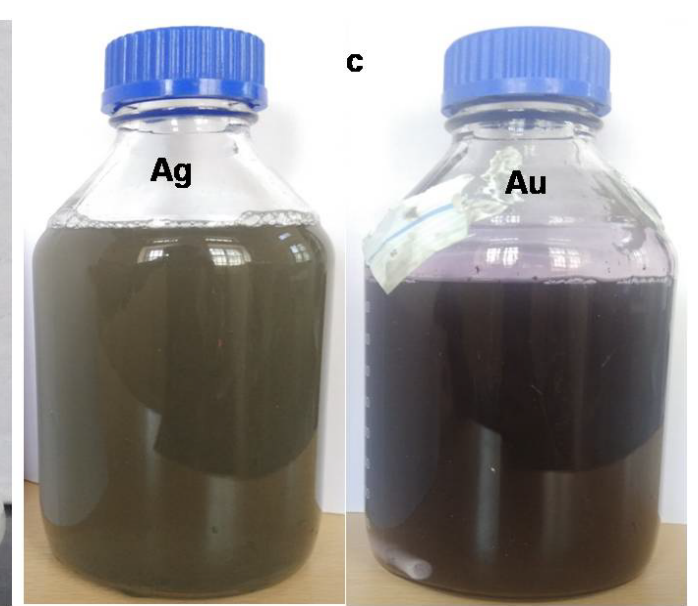

Fig. 1: a) Ledebouria hydrabadensis rhizome b) aqueous rhizomes extract c) Synthesized Ag and Au colloidal nanoparticles solutions 


\section{Phytofabrication of Ag and Au nanoparticles:}

Three Ag and three Au nanoparticles fabricated using three different methods, such as stirring, ultrasonic water bath and autoclave. The aqueous solutions of $1 \mathrm{mM}$ silver nitrate and $0.25 \mathrm{mM}$ chloroauric acid metal salts are used in this study. $900 \mathrm{ml}$ of aqueous metal solution kept for stirring at $500 \mathrm{rpm}, 40^{\circ}$, and 100 $\mathrm{ml}$ of Ledebouria hydrabadensis aqueous plant extract is added dropwise from the burette for the synthesis of nanoparticles using magnetic stirrer method. The synthesis of nanoparticles using an autoclave method, to $900 \mathrm{ml}$ of aqueous metal solution, $100 \mathrm{ml}$ of Ledebouria hydrabadensis aqueous plant extract directly added, kept for stirring for $5 \mathrm{~min}$ to proper mixing of solutions then transferred into the autoclave for $30 \mathrm{~min}$ and $15 \mathrm{lbs}$ pressure. Synthesis of nanoparticles using sonication method, to $900 \mathrm{ml}$ of aqueous metal solution $100 \mathrm{ml}$ of Ledebouria hydrabadensis aqueous rhizome extract directly added, kept for stirring for $5 \mathrm{~min}$ to proper mixing of solutions then transferred into an ultrasonic water bath $(20-40 \mathrm{kHz})$ at $60^{\circ}$. After completion of the reaction, the Ag nanoparticles solution exhibited brown color and Au nanoparticles exhibited violet color indicating the formation of colloidal nanoparticles. Fig. 1 displaying the rhizome of Ledebouria hydrabadensis plant source, aqueous rhizome extract and synthesized $\mathrm{Ag}, \mathrm{Au}$ colloidal nanoparticles solutions. The concentrated colloidal metal nanoparticles solution was obtained by centrifugation of the nanoparticles solution at $10000 \mathrm{rpm}$ for $15 \mathrm{~min}$. To get rid of extra unbound plant material, concentrated colloidal metal nanoparticles solution washed with distilled water twice then transferred into a crucible and kept in a hot air oven for $12 \mathrm{~h}$ at $60^{\circ}$. The dehydrated metal nanoparticles ground to obtain fine powder used for further characterization and advanced applications.

\section{Characterization of Ag and Au nanoparticles:}

The constitution of $\mathrm{Ag}$ and $\mathrm{Au}$ nanoparticles by reduction of $\mathrm{Ag}^{+}$and $\mathrm{Au}^{+}$ions monitored by UltravioletVisible (UV-Vis) spectroscopy. The 200-800 nm wavelength range selected with the baseline correction done by distilled water. Small aliquot colloidal nanoparticles from the reaction mixture solution mixed with distilled water and UV-Vis spectral analysis served by using the instrument, UV $2600 \mathrm{UV}$-Vis Spectrophotometer, Shimadzu. Fourier Transform Infrared spectroscopy (FTIR) analysis by $\mathrm{KBr}$ pellet technique produced by $1 \mathrm{mg}$ of synthesized $\mathrm{Ag}$ and $\mathrm{Au}$ nanoparticles ground with a small amount of $\mathrm{KBr}$ in a clean mortar separately. The aqueous rhizome extracts directly analyzed by keeping the one drop of aqueous rhizome extract on lenses. The FTIR spectra of phytofabricated Ag and Au nanoparticles recorded with IR Affinity-1, Shimadzu, selected wavelength range between $4500-500 \mathrm{~cm}^{-1}$. X-ray diffraction analysis (XRD) of $\mathrm{Ag}$ and $\mathrm{Au}$ nanoparticles carried out by spreading the metallic nanopowder as a thin layer on a clean glass slide. XRD performed with Philips Xpert Pro instrument with $\mathrm{Cuk} \alpha \mathrm{X}$-ray source with generator settings $40 \mathrm{kV}, 30 \mathrm{mAh}$ with scanning rate $2^{\circ} \mathrm{min}^{-1}$ in $\theta=2 \theta$ configuration. Transmission electron microscopy (TEM) images obtained by a small amount of metallic nano-powder dispersed in $1 \mathrm{ml}$ distilled water followed sonicated for 30 min using an ultrasonic water bath. A drop of the sample placed on a carbon-coated copper grid placed on a piece of par film, drain the excess with the help of filter paper and wait for 5-10 min to dry. Latter observed under TEM at various magnifications using model FEI Tecnai G2 S Twin.

\section{Antibacterial activity:}

The antibacterial activity of $\mathrm{Ag}$ and $\mathrm{Au}$ nanoparticles fabricated using various methods from Ledebouria hydrabadensis rhizome extract tested by using the agar well-diffusion method. In this method, the fresh actively growing bacterial cultures of two selected bacteria, Escherichia coli and Bacillus subtilis prepared. Nutrient agar media prepared by dissolving 2.8 gm nutrient agar in $100 \mathrm{ml}$ distilled water then autoclaved. Bacterial cultures spread individually onto Muller-Hinton agar plates and wells were made using sterile borer, then respective samples were added. To these wells, $100 \mu 1$ of each compound dissolved in DMSO $(1 \mathrm{mg} / \mathrm{ml})$ was added and incubated at $37^{\circ}$ for $24 \mathrm{~h}$ to observe the zone of inhibition, which diameter measured in $\mathrm{mm} .1 \mathrm{mg}$ Streptomycin dissolved in $1 \mathrm{ml}$ distilled water was used as a control in this study.

\section{Antifungal activity of human and plant pathogenic fungi:}

The antifungal activity was detected by the agar well diffusion method ${ }^{[43]}$. Soil-borne plant pathogenic fungi, Sclerotium rolfsii and Rhizoctonia solani, and the human pathogenic fungus Aspergillus flavus was grown on Potato Dextrose Agar (PDA) media. An agar block (five $\mathrm{mm}$ dia) was cut from an actively growing (96 $h$ old) fungal culture and placed on the surface of the fresh agar medium at the centre of the Petri plate. After that, $100 \mu 1$ of each compound $(1 \mathrm{mg} / \mathrm{mL})$ dissolved in Dimethyl sulfoxide (DMSO) was added to each well 
and incubated for $24 \mathrm{~h}$, then the zone of inhibition observed. Plates inoculated with the same fungus without compound used as control. Two replications maintained for each and reduction in radial growth was measured.

\section{RESULTS AND DISCUSSION}

UV-Vis spectroscopy is a prominently used technique ${ }^{[44]}$ in the case of metallic nanoparticles preparation as a primary tool. The preliminary examination of the formation of colloidal nanoparticles observed visually shows a distinctive brown color for $\mathrm{Ag}$ and deep violet color in the case of $\mathrm{Au}$ nanoparticles. The color change due to combined surface electronic oscillations called surface plasmon resonance ${ }^{[45]}$ was a characteristic property of metallic $\mathrm{Ag}$ and $\mathrm{Au}$ nanoparticles. It varies with the size, concentration of the colloidal metal solution ${ }^{[46,47]}$. The formed colloidal Ag nanoparticles exhibited maximum absorption peaks between $420-450 \mathrm{~nm}$ and $530-600 \mathrm{~nm}$ in the case of $\mathrm{Au}$ nanoparticles. UV-Vis spectroscopy of Ag and $\mathrm{Au}$ colloidal nanoparticles synthesized using autoclave are showing maximum absorption peaks $\lambda_{\max }$ at $436 \mathrm{~nm}$ and $556 \mathrm{~nm}$, respectively in fig. 2. The surface plasmon resonance peaks are the characteristic absorption peaks ${ }^{[48]}$, proving the formation of respective stabilized colloidal nanoparticles. In addition, a flat curve in UV-Vis spectroscopy suggesting the polydistributed nanoparticles in the colloidal solution. According to Krishnaraj et al. ${ }^{[49]}$, a single peak indicates spherical particles, whereas many peaks indicate anisotropic particles. The examination of UV-Vis spectroscopy showing the reduction process of $\mathrm{Ag}^{+}$and $\mathrm{Au}^{+}$ions into phytomediated stabilized $\mathrm{Ag}$ and $\mathrm{Au}$ nanoparticles.

The biological synthesis processes of metallic nanoparticles generally monitored by FTIR analysis.
The FTIR analysis provides information about the possible active phytochemicals compounds involving in the reduction reaction. The increasing phytochemicals involvement in the reduction will give more intense bands in the spectra ${ }^{[18,50]}$. The stabilization process occurred by surrounding these active components on the surface of Ag and Au nanoparticles. The characteristic vibrational bonds within the IR region of functional groups belong to active components are identified. The IR spectra exhibiting the vibrational bonds of $\mathrm{Ag}$ and $\mathrm{Au}$ nanoparticles synthesized using various methods along with rhizome extract shown in fig. 3 . The prominent bands observed in the IR spectra at $3434 \mathrm{~cm}^{-1}, 3072 \mathrm{~cm}^{-1}, 1799 \mathrm{~cm}^{-1}, 1637 \mathrm{~cm}^{-1}, 1377 \mathrm{~cm}^{-1}$ and $1220 \mathrm{~cm}^{-1}$. The broadband observed at $3448 \mathrm{~cm}^{-1}$ suggests the strong stretching vibration of a hydroxyl group $(-\mathrm{OH})$ from alcohol or phenolic compounds. The less intense bands at $3072 \mathrm{~cm}^{-1}$ attribute to $\mathrm{NH}_{3}^{+}$ of amino acids, intense bands at $1799 \mathrm{~cm}^{-1}$ assigned to $\mathrm{C}=\mathrm{O}$ anhydride of carboxylic acid derivatives. The bands at $1637 \mathrm{~cm}^{-1}$ due to $\mathrm{N}-\mathrm{H}$ vibrations of $1^{\circ}$ amines, weak intense band at $1379 \mathrm{~cm}^{-1}$ indicate $\mathrm{N}-\mathrm{O}$ vibrations of aliphatic nitro compounds. The less intense band at 1220 arises due to the $\mathrm{C}-\mathrm{O}$ stretching vibrations of phenols. According to Wu et al. ${ }^{[51]}$, proteins and amino acids having more reactive towards ions to produce stable nanoparticles, thus proteins involved in the stabilization process $^{[52]}$. In the case of Ag nanoparticles, above stated all compounds are involved, but for $\mathrm{Au}$ nanoparticles, only proteins and phenols involved in the phytoreduction process. A similar observation was noticed in the biological synthesis of $\mathrm{Ag}$ nanoparticles using leaf extract of Mimusops elengi ${ }^{[53]}$, Jatropha curcas seed extract ${ }^{[54]}$ and Banana peel extract ${ }^{[55]}$.

Phytofabricated $\mathrm{Ag}$ and $\mathrm{Au}$ nanoparticles subjected to XRD analysis, unveil the crystalline nature. The attribute
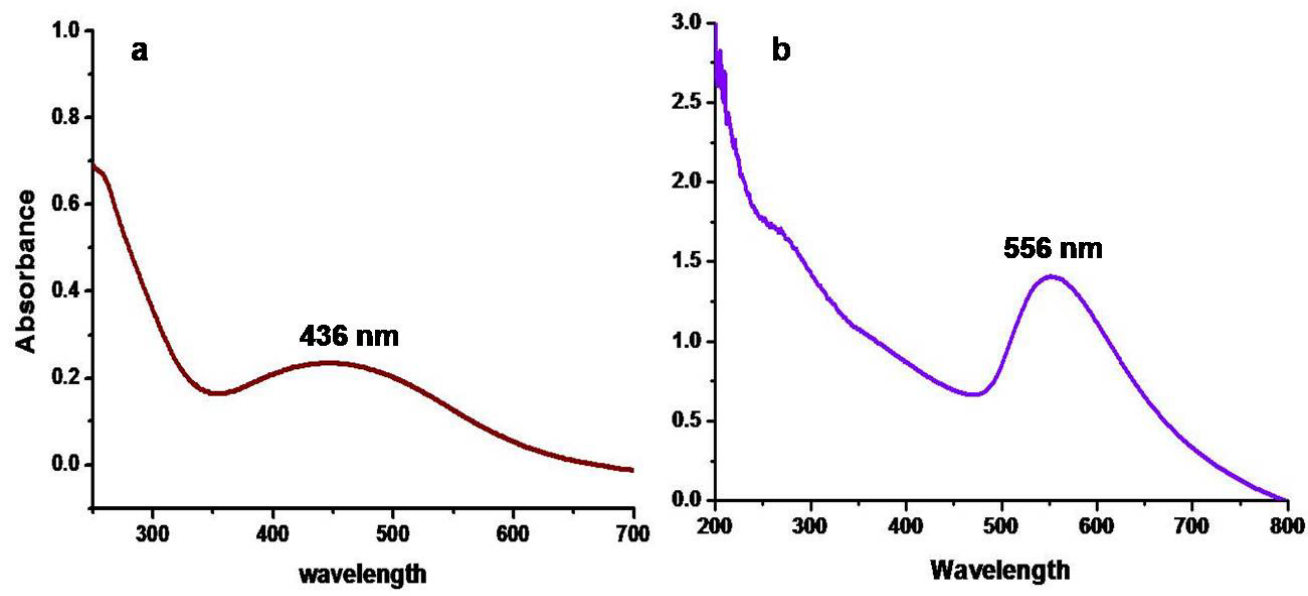

Fig. 2: UV-Vis spectroscopy of a) Ag nanoparticles b) Au nanoparticles synthesized using autoclave method 


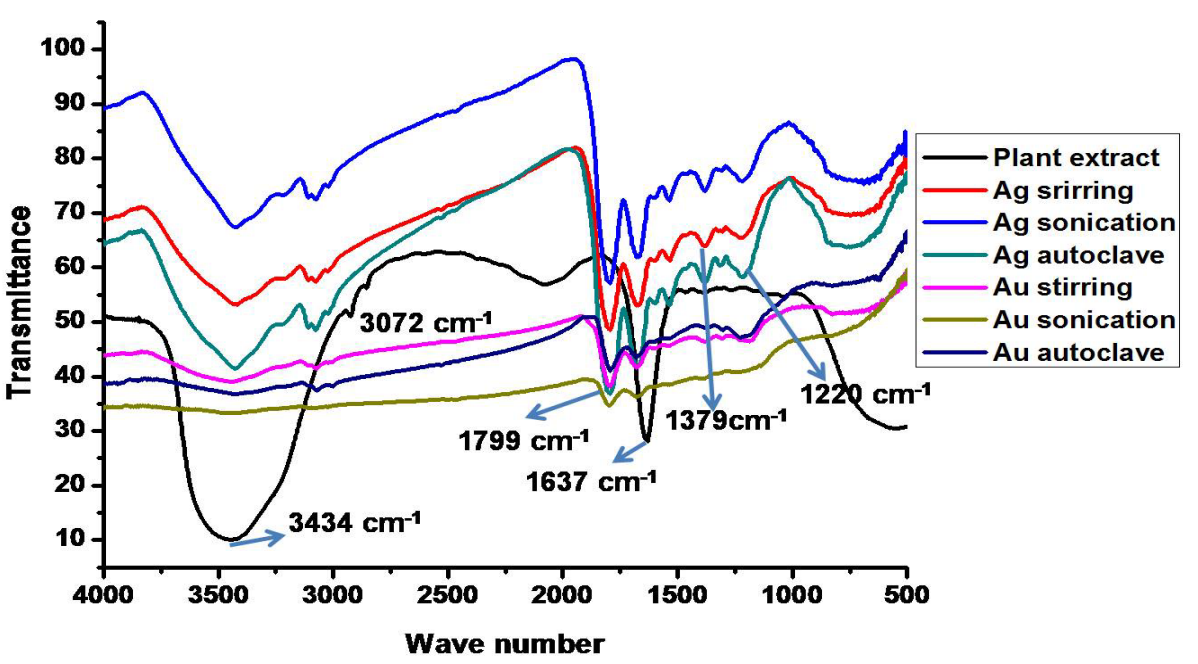

Fig. 3: FTIR Spectroscopy of Ag and Au nanoparticles synthesized by various methods

peaks of $2 \theta$ degrees in fig. 4, suggesting the highly crystalline nature of both $\mathrm{Ag}$ and $\mathrm{Au}$ nanoparticles. The four distinct diffraction peaks observed for each Ag nanoparticles at $2 \theta=37.8482^{\circ}, 45.8347^{\circ}, 67.1296^{\circ}$, $76.4299^{\circ}$. The results indexed for the face-centric cubic crystalline structure of Ag nanoparticles and it was matched with the JCPDS data file no. 65-2871. Three Au nanoparticles notified around at $2 \theta=37.83^{\circ}, 43.92^{\circ}$, $64.26^{\circ}$ and $77.29^{\circ}$, those understood to be (111) (200) (220) and (311) lattice planes, respectively. In the case of Ag nanoparticles, other unassigned peaks observed are due to the crystallization of other biological materials found on the surface of Ag nanoparticles ${ }^{[56]}$. The results correlated with previously published articles by Balaji et al. ${ }^{[57]}$, Krishnaraj et al. ${ }^{[50]}$, Suvith et al.$^{[58]}$. The average particle size calculated from the following DebyeScherrer equation. The average particle sizes for $\mathrm{Ag}$ nanoparticles synthesized using various methods found to be $150 \mathrm{~nm}$ for stirring, $20 \mathrm{~nm}$ for sonication, $9 \mathrm{~nm}$ for an autoclave. Au nanoparticles, $45 \mathrm{~nm}$ for stirring, $38 \mathrm{~nm}$ for sonication, $16 \mathrm{~nm}$ for autoclaved proved to be the same and well-matched with the particle sizes exhibited in TEM images.

$\mathrm{D}=K \lambda / \beta_{(0.5)} \cos \square \theta$ Where $\beta=\pi / 180 \times \mathrm{FWHM}$

$K$ is Scherrer constant with a value from 0.9 to 1 (shape factor), $\lambda$ is X-ray Wavelength (1.5418 $\AA$ ), $\theta$ is Braggs angle and the FWHM is full width at half maximum.

The morphological studies such as size, shape and distribution obtained from Transmission electron microscopy images. TEM images in fig. 5 clearly depicting the nano-sized $\mathrm{Ag}$ and $\mathrm{Au}$ nanoparticles. The average particle size was observed below $100 \mathrm{~nm}$ in all the cases except Ag nanoparticles synthesized using stirring; least size and fine nanoparticles found in the case of $\mathrm{Ag}$ and $\mathrm{Au}$ nanoparticles synthesized using the autoclave method. So these are used further in applications. Mono distributed, spherical-shaped Ag nanoparticles and polydistributed, spherical-shaped $\mathrm{Au}$ nanoparticles were found. Agglomerated flower-like shaped Au nanoparticles observed from synthesis using the stirring method, while aggregation observed in the case of Au nanoparticles synthesis from the sonication method. Precise spherical shaped Au nanoparticles observed in the case of an autoclave method. The selected area electron diffraction (SAED) patterns of colloidal $\mathrm{Ag}$ and $\mathrm{Au}$ nanoparticles were shown in fig. 6. The bright spots and circular rings in typical SAED patterns correspond to the lattice plane of Braggs reflections ${ }^{[59,60]}$ indicate (111) (200) (220) and (311) are proving synthesized Ag and Au nanoparticles are highly crystalline structure in nature.

Metal nanoparticles, especially Ag and Au nanoparticles extensively used in the antimicrobial effects from the last decades ${ }^{[61]}$. The antibacterial activity of Ag nanoparticles previously reported against pathogenic bacteria ${ }^{[62]}$. Antibacterial activity was done by agar well-diffusion method $^{[60]}$ against human pathogenic bacteria Bacillus subtilis, Escherichia coli. The effect of antibacterial activity varies with change in the morphology of nanoparticles, such as different sizes, shapes, etc ${ }^{[63]}$. The zone of inhibition of $\mathrm{Ag}$ and $\mathrm{Au}$ nanoparticles synthesized using the autoclave method shown in fig. 7. The Ag and Au nanoparticles exhibited $0.2 \mathrm{~cm}, 0.3$ $\mathrm{cm}$ against Bacillus subtilis and $0.3 \mathrm{~cm}, 0.2 \mathrm{~cm}$ against Escherichia coli respectively and control sample streptomycin showed $4 \mathrm{~cm}$ of the zone of inhibition. Previous reports Muthukrishnan et al. ${ }^{[64]}$, Murugan et $a l .{ }^{[65]}$ showed similar results of antibacterial activity in the case of Ag nanoparticles from biological synthesis. The zone of inhibition against phytopathogenic fungi by 

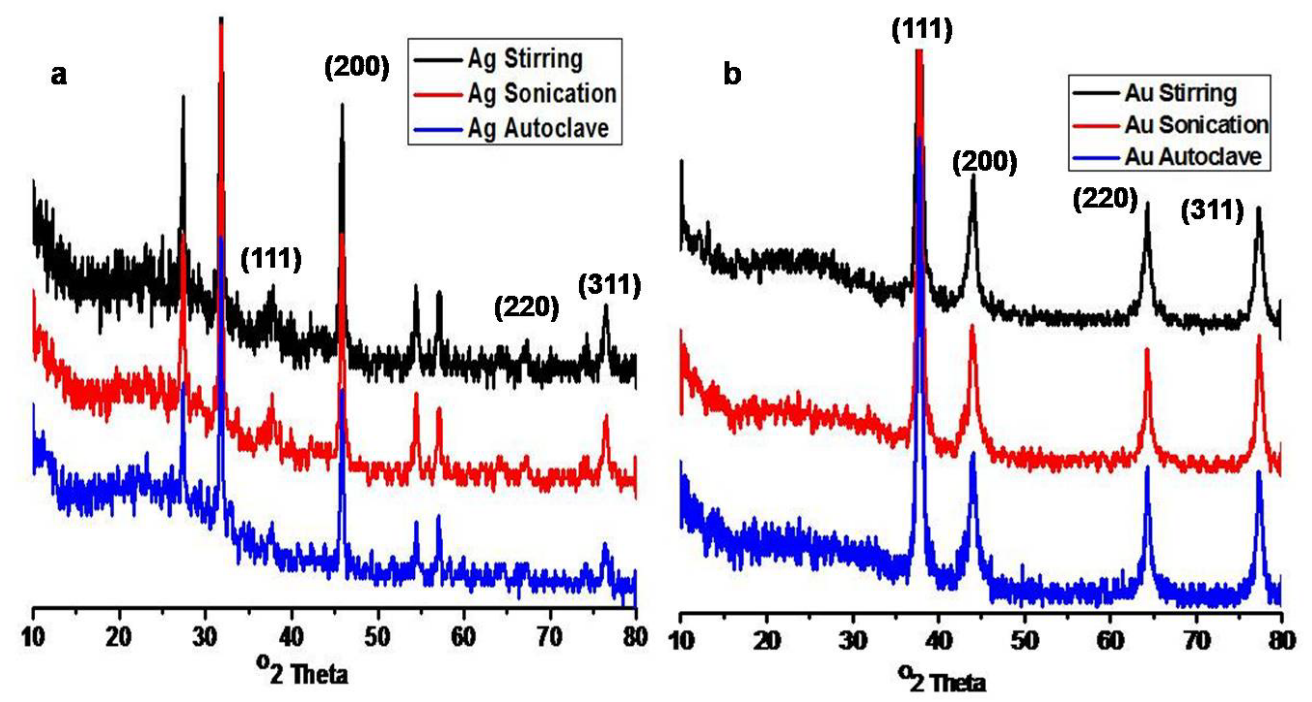

Fig. 4: XRD spectra of Ag and Au nanoparticles synthesized by various methods

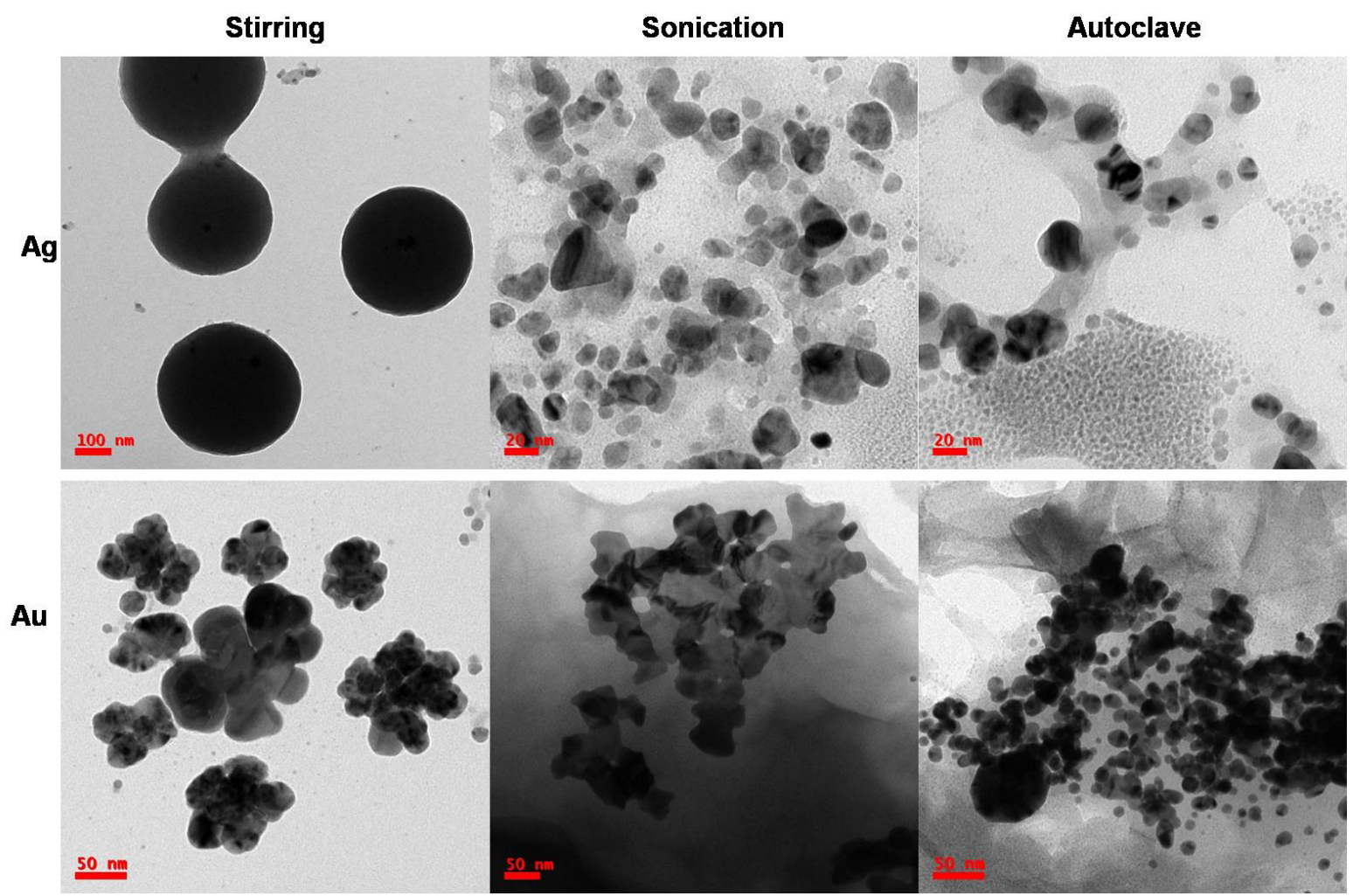

Fig. 5: TEM Images of Ag and Au nanoparticles synthesized by various methods

$\mathrm{Ag}$ and Au nanoparticles on Sclerotium rolfsi exhibited as $1.5 \mathrm{~cm}, 1.3 \mathrm{~cm}$, against Rhizoctonia solani $1.3 \mathrm{~cm}$, $1.6 \mathrm{~cm}$, respectively and control sample showed $2.5 \mathrm{~cm}$ in this case. Zone of inhibition for human pathogenic fungi Aspergillus flavus exhibited as $0.5 \mathrm{~cm}, 1 \mathrm{~cm}$ for $\mathrm{Ag}$ and $\mathrm{Au}$ nanoparticles and control sample showed $3 \mathrm{~cm}$. According to Kim et al. ${ }^{[40]}$, Huang et al. ${ }^{[66]}$, the antibacterial and antifungal activity mainly caused by metallic nanoparticles penetrate and cause damage to the cell wall of pathogens. The results proved phytofabricated $\mathrm{Ag}$ and $\mathrm{Au}$ nanoparticles deliver considerable antimicrobial activities against human pathogenic fungi, plant pathogenic fungi and bacteria.

In conclusion $\mathrm{Ag}$ and $\mathrm{Au}$ nanoparticles successfully fabricated using a simple one-pot reduction method which not involved toxic chemicals by three different methods. The visual observation of color change indicates the formation of colloidal $\mathrm{Ag}$ and $\mathrm{Au}$ nanoparticles. The SPR peaks of UV-Vis spectroscopy confirm the constitution of colloidal $\mathrm{Ag}$ and $\mathrm{Au}$ nanoparticles. The phytochemicals mainly proteins from rhizome extract of Ledebouria hydrabadensis 


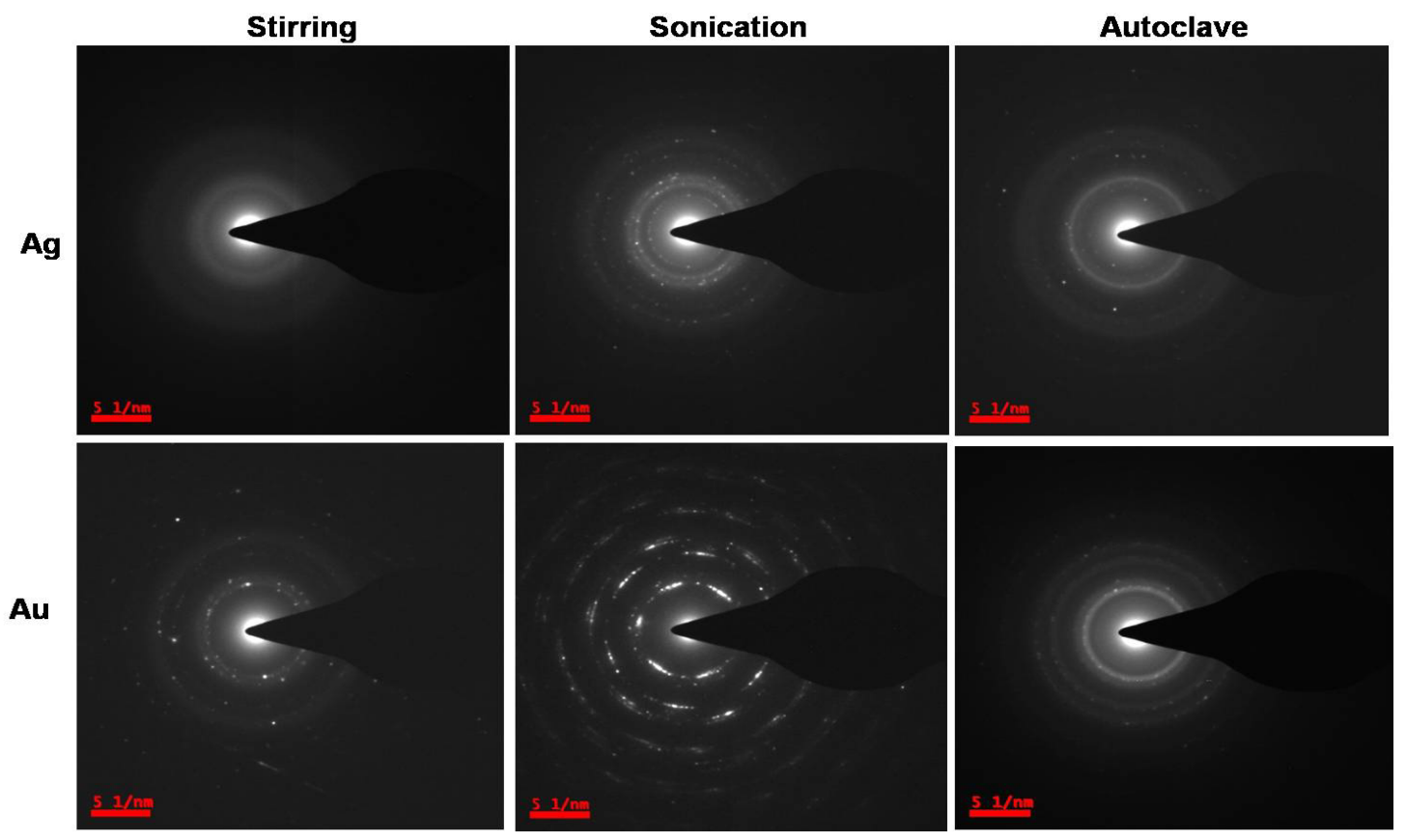

Fig. 6: SAED pattern of Ag and Au nanoparticles synthesized by various methods
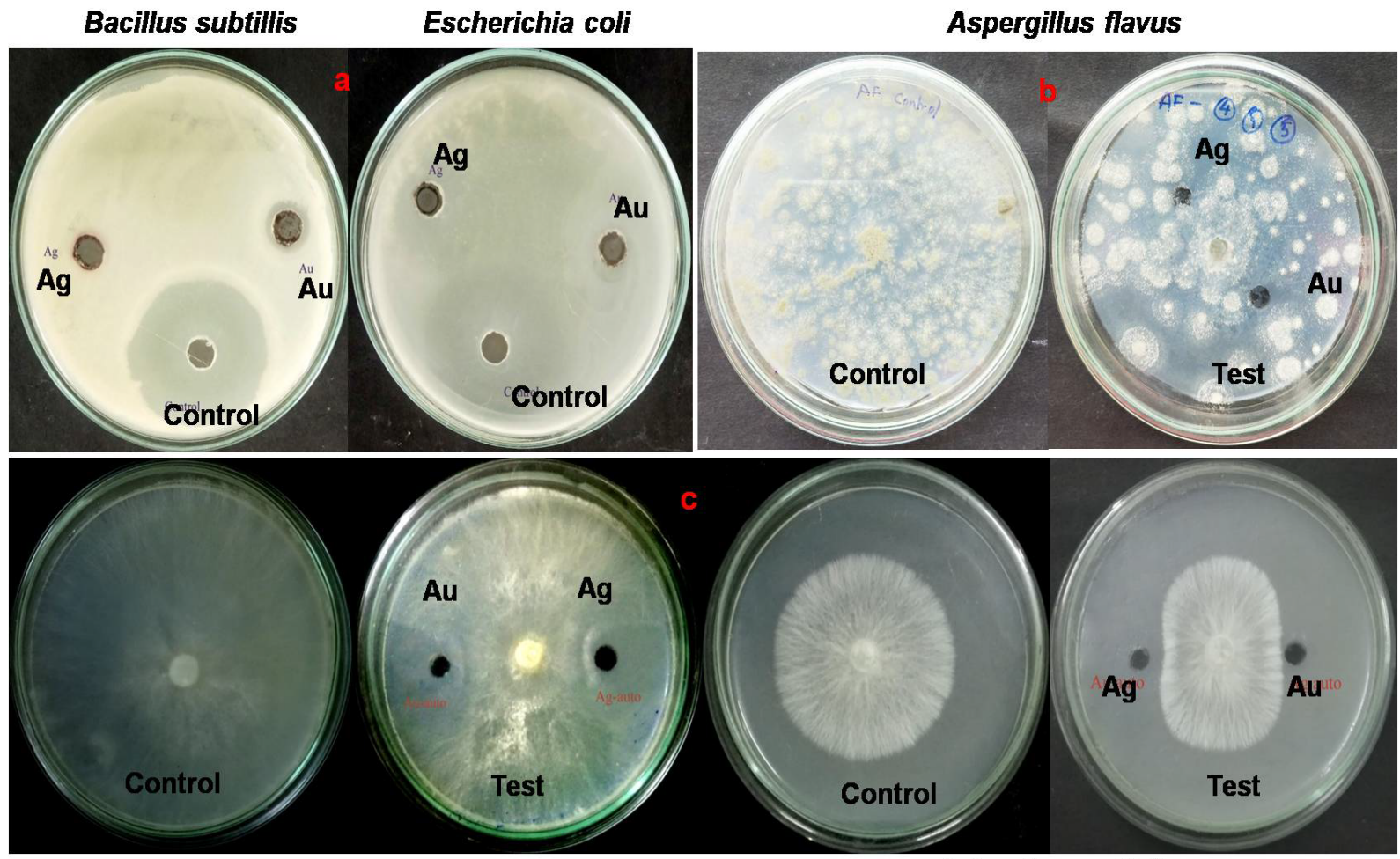

Rhizoctonia solani

\section{Sclerotium rolfsii}

Fig. 7: a) Antibacterial activity-zone of inhibition, b) Antifungal activity of human pathogenic fungi, c) Antifungal activity of phytopathogenic fungi of Ag and Au nanoparticles synthesized using the autoclave method

involving in reduction reaction clearly indicated by FTIR analysis. In most cases, the average particle size found to be below $50 \mathrm{~nm}$ and crystalline in nature proved by X-ray diffraction studies and TEM images. The clear monoclinic, anisotropic, spherical shaped particles exhibited in TEM images. The tested results were showing the fabricated $\mathrm{Ag}$ and $\mathrm{Au}$ nanoparticles producing good antimicrobial activity against phytopathogenic fungi and human pathogenic fungi as well as bacteria. The simplicity in fabrication, ease of availability and renewable plant sources makes these processes useful in the bulk production of biologically active metallic nanoparticles. 


\section{Acknowledgments:}

The authors gratefully acknowledge the Forensic science unit, Department of Chemistry, for providing facilities to carry out the research work. Authors thankful to the University Grants Commission, New Delhi, India for the senior research fellowship award to Sandupatla Raju and BSR Fellowship to D. Ashok.

\section{Conflict of interests:}

The authors declared no conflict of interest.

\section{REFERENCES}

1. Raveendran P, Fu J, Wallen SL. Completely "Green" Synthesis and Stabilization of Metal Nanoparticles. J Am Chem Soc 2003;125(46):13940-1.

2. Mittal AK, Chisti Y, Banerjee UC. Synthesis of metallic nanoparticles using plant extracts. Biotechnol Adv 2013;31(2):346-56.

3. Vankar PS, Bajpai D. Preparation of gold nanoparticles from Mirabilis jalapa flowers, Indian J Biochem Biophys 2010;47(3):157-60.

4. Otari SV, Patil RM, Nadaf NH, Ghosh SJ, Pawar SH. Green biosynthesis of silver nanoparticles from an actinobacteria Rhodococcus sp. Mater Lett 2012;72:92-4.

5. Mohanpuria P, Rana NK, Yadav SK. Biosynthesis of nanoparticles: technological concepts and future applications. J Nanopart Res 2008;10(3):507-17.

6. Sharma D, Kanchi S, Bisetty K. Biogenic synthesis of nanoparticles: A review. Arab J Chem 2019;12(8):3576-600.

7. Iravani S. Green synthesis of metal nanoparticles using plants. Green Chem 2011;13(10):2638-50.

8. Patra CR, Bhattacharya R, Mukhopadhyay D, Mukherjee P. Fabrication of gold nanoparticles for targeted therapy in pancreatic cancer. Adv Drug Deliv Rev 2010;62(3):346-61.

9. Shankar PD, Shobana S, Karuppusamy I, Pugazhendhi A, Ramkumar VS, Arvindnarayan S, et al. A review on the biosynthesis of metallic nanoparticles (gold and silver) using bio-components of microalgae: Formation mechanism and applications. Enzyme and Microb Technol 2016;95:28-44.

10. Gardea-Torresdey JL, Gomez E, Peralta-Videa JR, Parsons JG, Troiani H, Jose-Yacaman M. Alfalfa Sprouts: A Natural Source for the Synthesis of Silver Nanoparticles. Langmuir 2003;19(4):1357-61.

11. Narayanan KB, Sakthivel N. Coriander leaf mediated biosynthesis of gold nanoparticles. Mater Lett 2008;62(30):4588-90.

12. Shankar SS, Rai A, Ankamwar B, Singh A, Ahmad A, Sastry M. Biological synthesis of triangular gold nanoprisms. Nat Mater 2004;3(7):482-8.

13. Chandran SP, Chaudhary M, Pasricha R, Ahmad A, Sastry M. Synthesis of Gold Nanotriangles and Silver Nanoparticles Using Aloe vera Plant Extract. Biotechnol Prog 2006;22(2):577-83.

14. Shankar SS, Rai A, Ahmad A, Sastry M. Rapid synthesis of $\mathrm{Au}, \mathrm{Ag}$, and bimetallic Au core-Ag shell nanoparticles using Neem (Azadirachta indica) leaf broth. J Colloid Interface Sci 2004;275(2):496-502.

15. Zayed MF, Eisa WH, Shabaka AA. Malva parviflora extract assisted green synthesis of silver nanoparticles. Spectrochim Acta A 2012;98:423-8.
16. Shankar SS, Ahmad A, Sastry M. Geranium Leaf Assisted Biosynthesis of Silver Nanoparticles. Biotechnol Prog 2003;19(6):1627-31.

17. Philip D. Biosynthesis of $\mathrm{Au}, \mathrm{Ag}$ and $\mathrm{Au}-\mathrm{Ag}$ nanoparticles using edible mushroom extract. Spectrochim Acta A 2009;73(2):374-81.

18. Philip D. Honey mediated green synthesis of gold nanoparticles. Spectrochim Acta A 2009;73(4):650-3.

19. Nirmala Grace A, Pandian K. Antibacterial efficacy of aminoglycosidic antibiotics protected gold nanoparticles-A brief study. Colloids Surf, A Physicochem Eng Asp 2007;297:63-70.

20. Kurek A, Grudniak AM, Kraczkiewicz-Dowjat A, Wolska KI. New Antibacterial Therapeutics and Strategies. Pol J Microbiol 2011;60(1):3-12.

21. Mathew TV, Kuriakose S. Studies on the antimicrobial properties of colloidal silver nanoparticles stabilized by bovine serum albumin. Colloids Surf B 2013;101:14-8.

22. Jeyaraj M, Sathishkumar G, Sivanandhan G, MubarakAli D, Rajesh M, Arun R, et al. Biogenic silver nanoparticles for cancer treatment: An experimental report. Colloids Surf B 2013;106:86-92.

23. Singh KP, Singh AK, Gupta S, Rai P. Modeling and optimization of reductive degradation of chloramphenicol in aqueous solution by zero-valent bimetallic nanoparticles. Environ Sci Pollut Res 2012;19(6):2063-78.

24. Vijay Kumar PPN, Pammi SVN, Kollu P, Satyanarayana KVV, Shameem U. Green synthesis and characterization of silver nanoparticles using Boerhaavia diffusa plant extract and their anti- bacterial activity. Ind Crop Prod 2014;52:562-6.

25. Alkhathlan H, Khan M, Khan ST, Khan M, Adil SF, Musarrat $\mathrm{J}$, et al. Antibacterial properties of silver nanoparticles synthesized using Pulicaria glutinosa plant extract as a green bioreductant. Int J Nanomedicine 2014;9:3551.

26. Balavigneswaran CK, Sujin Jeba Kumar T, Moses Packiaraj $\mathrm{R}$, Prakash S. Rapid detection of $\mathrm{Cr}(\mathrm{VI})$ by AgNPs probe produced by Anacardium occidentale fresh leaf extracts. Appl Nanosci 2014;4(3):367-78.

27. Ganaie SU, Abbasi T, Anuradha J, Abbasi SA. Biomimetic synthesis of silver nanoparticles using the amphibious weed ipomoea and their application in pollution control. J King Saud Univ Sci 2014;26(3):222-9.

28. Mukherjee P, Ahmad A, Mandal D, Senapati S, Sainkar SR, Khan MI, et al. Fungus-Mediated Synthesis of Silver Nanoparticles and Their Immobilization in the Mycelial Matrix: A Novel Biological Approach to Nanoparticle Synthesis. Nano Lett 2001;1(10):515-9.

29. Cantu AA. Nanoparticles in forensic science. InOptics and Photonics for Counterterrorism and Crime Fighting IV. SPIE 2008;7119:71190.

30. Li H, Li F, Wang L, Sheng J, Xin Z, Zhao L, et al. Effect of nano-packing on preservation quality of Chinese jujube. Food Chem 2009;114(2):547-52.

31. Park HJ, Kim SH, Kim HJ, Choi SH. A New Composition of Nanosized Silica-Silver for Control of Various Plant Diseases. Plant Pathol J 2006;22(3):295-302.

32. Wei D, Qian W. Facile synthesis of Ag and Au nanoparticles utilizing chitosan as a mediator agent. Colloids Surf B 2008;62(1):136-42.

33. Huang SH. Gold nanoparticle-based immune chromatographic test for identification of Staphylococcus aureus from clinical specimens. Clinica Chimica Acta 2006;373:139-43.

34. Krpetić Ž, Anguissola S, Garry D, Kelly PM, Dawson KA. 
Nanomaterials: Impact on Cells and Cell Organelles. In: Capco DG, Chen Y, editors. Nanomaterial. Springer Netherlands: Dordrecht, 2014: 135-56.

35. Khan AU, Malik N, Khan M, Cho MH, Khan MM. Fungiassisted silver nanoparticle synthesis and their applications. Bioprocess Biosyst Eng 2018;41(1):1-20.

36. Chowdhury S, Basu A, Kundu S. Green synthesis of protein capped silver nanoparticles from phytopathogenic fungus Macrophomina phaseolina (Tassi) Goid with antimicrobial properties against multidrug-resistant bacteria. Nanoscale Res Lett 2014;9(1):365.

37. Radhakrishnan S, Munuswamy DB, Devarajan Y, T A, Mahalingam A. Effect of nanoparticle on emission and performance characteristics of a diesel engine fueled with cashew nut shell biodiesel. Energ Source Part A 2018;40(20):2485-93.

38. Huang Z, He K, Song Z, Zeng G, Chen A, Yuan L, et al. Antioxidative response of Phanerochaete chrysosporium against silver nanoparticle-induced toxicity and its potential mechanism. Chemosphere 2018;211:573-83.

39. Kim JS, Kuk E, Yu KN, Kim J-H, Park SJ, Lee HJ, et al. Corrigendum to "Antimicrobial effects of silver nanoparticles" [Nanomed Nanotechnol Biol Med. 2007;1:95-101]. Nanomedicine: NBM 2014;10(5):e1119.

40. Park, Hae-Jun, Kim, Sung Ho, Kim, Hwa-Jung. A New Composition of Nanosized Silica-Silver for Control of Various Plant Diseases. The Plant Pathology Journal 2006;22(3):295302.

41. Min, Ji-Seon, Kim, Kyoung-Su, Kim, Sang woo, Jung, Jin Hee, Kim, Seung-Bin. Effects of Colloidal Silver Nanoparticles on Sclerotium-Forming Phytopathogenic Fungi. Plant Pathol J 2009;25(4):376-80.

42. Mishra S, Singh HB. Biosynthesized silver nanoparticles as a nanoweapon against phytopathogens: exploring their scope and potential in agriculture. Appl Microbiol Biotechnol 2015;99(3):1097-107.

43. Osman Mohamed Ali E, Shakil NA, Rana VS, Sarkar DJ, Majumder S, Kaushik P, et al. Antifungal activity of nano emulsions of neem and citronella oils against phytopathogenic fungi, Rhizoctonia solani and Sclerotium rolfsii. Ind Crop Prod 2017;108:379-87.

44. Khanra K, Panja S, Choudhuri I, Chakraborty A, Bhattacharyya N. Evaluation of Antibacterial Activity and Cytotoxicity of Green Synthesized Silver Nanoparticles Using Scoparia Dulcis. Nano BioMed Eng 2015;7(3):128-33.

45. Vigneshwaran N, Ashtaputre NM, Varadarajan PV, Nachane RP, Paralikar KM, Balasubramanya RH. Biological synthesis of silver nanoparticles using the fungus Aspergillus flavus. Mater Lett 2007;61(6):1413-18.

46. Kumar V, Singh DK, Mohan S, Hasan SH. Photo-induced biosynthesis of silver nanoparticles using aqueous extract of Erigeron bonariensis and its catalytic activity against Acridine Orange. J Photoch Photobio B 2016;155:39-50.

47. Lee JH, Lim JM, Velmurugan P, Park YJ, Park YJ, Bang KS, et al. Photobiologic-mediated fabrication of silver nanoparticles with antibacterial activity. J Photoch Photobio B 2016;162:939.

48. Vilchis-Nestor AR, Sánchez-Mendieta V, Camacho-López MA, Gómez-Espinosa RM, Camacho-López MA, ArenasAlatorre JA. Solventless synthesis and optical properties of Au and Ag nanoparticles using Camellia sinensis extract. Mater Lett 2008;62(17-18):3103-5.

49. Krishnaraj C, Jagan EG, Rajasekar S, Selvakumar P,
Kalaichelvan PT, Mohan N. Synthesis of silver nanoparticles using Acalypha indica leaf extracts and its antibacterial activity against water borne pathogens. Colloids Surf B 2010;76(1):506.

50. Huang J, Li Q, Sun D, Lu Y, Su Y, Yang X, et al. Biosynthesis of silver and gold nanoparticles by novel sundried Cinnamomum camphora leaf. Nanotechnology 2007;18(10):105104.

51. Wu C-J, Gaharwar AK, Schexnailder PJ, Schmidt G. Development of Biomedical Polymer-Silicate Nanocomposites: A Materials Science Perspective. Materials 2010;3(5):29863005.

52. Gole A, Dash C, Ramakrishnan V, Sainkar SR, Mandale AB, Rao M, et al. Pepsin-Gold Colloid Conjugates: Preparation, Characterization, and Enzymatic Activity. Langmuir 2001;17(5):1674-9.

53. Prakash P, Gnanaprakasam P, Emmanuel R, Arokiyaraj S, Saravanan M. Green synthesis of silver nanoparticles from leaf extract of Mimusops elengi, Linn. for enhanced antibacterial activity against multi drug resistant clinical isolates. Colloids Surf B 2013;108:255-9.

54. Bar H, Bhui DKr, Sahoo GP, Sarkar P, Pyne S, Misra A. Green synthesis of silver nanoparticles using seed extract of Jatropha curcas. Colloids Surf, A Physicochem Eng Asp 2009;348:2126.

55. Bankar A, Joshi B, Kumar AR, Zinjarde S. Banana peel extract mediated novel route for the synthesis of silver nanoparticles. Colloids Surf, A Physicochem Eng Asp 2010;368:58-63.

56. Shanmugam N, Rajkamal P, Cholan S, Kannadasan N, Sathishkumar K, Viruthagiri G, et al. Biosynthesis of silver nanoparticles from the marine seaweed Sargassum wightii and their antibacterial activity against some human pathogens. Appl Nanosci 2014;4(7):881-8.

57. Balaji DS, Basavaraja S, Deshpande R, Mahesh DB, Prabhakar BK, Venkataraman A. Extracellular biosynthesis of functionalized silver nanoparticles by strains of Cladosporium cladosporioides fungus. Colloids Surf B 2009;68(1):88-92.

58. Suvith VS, Philip D. Catalytic degradation of methylene blue using biosynthesized gold and silver nanoparticles. Spectrochim Acta A 2014;118:526-32.

59. Vijayan SR, Santhiyagu P, Singamuthu M, Kumari Ahila $\mathrm{N}$, Jayaraman R, Ethiraj K. Synthesis and Characterization of Silver and Gold Nanoparticles Using Aqueous Extract of Seaweed, Turbinaria conoides, and Their Antimicrofouling Activity. Sci World J 2014;2014:1-10.

60. Patel V, Berthold D, Puranik P, Gantar M. Screening of cyanobacteria and microalgae for their ability to synthesize silver nanoparticles with antibacterial activity. Biotechnol Rep 2015;5:112-9.

61. Geethalakshmi R, Sarada. Gold and silver nanoparticles from Trianthema decandra: synthesis, characterization, and antimicrobial properties. Int J Nanomedicine 2012;7:5375.

62. Morones JR, Elechiguerra JL, Camacho A, Holt K, Kouri JB, Ramírez JT, et al. The bactericidal effect of silver nanoparticles. Nanotechnology 2005;16(10):2346-53.

63. Shafaghat A. Synthesis and Characterization of Silver Nanoparticles by Phytosynthesis Method and Their Biological Activity. Synth React Inorg M 2015;45(3):381-7.

64. Muthukrishnan S, Bhakya S, Senthil Kumar T, Rao MV. Biosynthesis, characterization and antibacterial effect of plantmediated silver nanoparticles using Ceropegia thwaitesii-An endemic species. Ind Crop Prod 2015;63:119-24.

65. Duraisamy S, Kasi M, Balakrishnan S, Al-Sohaibani S. Biosynthesis of silver nanoparticles using Acacia leucophloea 
www.ijpsonline.com

extract and their antibacterial activity. Int $\mathrm{J}$ Nanomedicine 2014;9:2431.

66. Huang Z, He K, Song Z, Zeng G, Chen A, Yuan L, et al.
Antioxidative response of Phanerochaete chrysosporium against silver nanoparticle-induced toxicity and its potential mechanism. Chemosphere 2018;211:573-83. 